This is an Accepted Manuscript of an article published by Taylor \& Francis in Journal of War and Culture Studies on 7 November 2017, available online:

http://www.tandfonline.com/10.1080/17526272.2017.1396743 . 


\section{The Recovery and Commemoration of War Dead from Post-Colonial Contexts}

This issue explores the recovery and commemoration of war dead who died while part of a colonial or imperial force, as soldiers, or as labourers under military command. This category of war dead is associated with particular complexities and challenges, shaped by relationships of colonialism and imperialism that still reverberate strongly in the present. There has been a very large academic output on the theme of war death and the commemoration of war (Capdevila and Voldman, 2006), and, in recent decades, a growing body of work on the experiences and representations of those soldiers who fought as part of colonial or imperial armies (Das, 2011). However, the specific questions of what happens to those who die in war as part of imperial armies or labour forces, their final resting place, how their physical remains are cared for, and how the dead are remembered in the contemporary societies of both former colonies and former colonial powers, all remain as important themes to be addressed.

The articles here explore what happens when the political and cultural relationships between former imperial powers and the nations that once constituted their empire undergo significant change. The meaning of dying in war as part of a colonial force will be dramatically altered once that colonial relationship has ended; yet the bodies of the dead remain as enduring physical traces of armies and polities that no longer exist. The changing status of the dead must be negotiated and represented in new commemorative practices. The bodies, images, cemeteries, and monuments associated with the dead may all become a medium through which to represent political and social change, or may stubbornly resist these new narratives. The dead are potentially a rich representational space, used instrumentally by those in the present to construct a particular version of colonial history. As signifiers of a common past, and a shared experience of sacrifice and loss, they can reiterate the bonds between countries, as a focus of 'memorial diplomacy' (Wellings, 2014). Conversely, if the histories they represent are too painful, or cannot be reconciled with contemporary national identities, the dead may not be represented at all, and will fall into neglect.

The examples gathered together here encompass histories from Asia, Europe, the United States, Canada, and Australia, and are a convincing illustration of the spatial links woven by both war and imperialism. Oliver's article focuses on the fragile and 
long-neglected memory of the romusha, the massive civilian labour force mobilized by the Japanese Imperial army during their occupation of South East Asia. Recruited or seized under varying degrees of duress, millions of men, women and children were forcibly relocated across Asia to work on constructing infrastructure such as bridges and railways. The unimaginably brutal conditions faced by these labourers resulted in appalling death rates, with only a small minority returning home to bear witness to what had happened to the rest. The trauma experienced by Indonesian romusha was compounded by the political context to which they returned. The national narrative under construction in the newly-Independent Indonesia left no space to represent these traumas (Hovinga, 2005). The Dutch former-colonizers were identified as the primary oppressors, and the collaboration of Sukarno's independence movement in the exploitation of the romushas was suppressed. It was not politically expedient to acknowledge that millions of Indonesians had also been victims of Japan's Imperial ambitions (Gouda, 2014). Oliver's article is also an excellent illustration of the diverse material registers encountered when looking for war dead, especially those whose deaths have been marginalised and neglected. Her contribution explores the haunting power of bodies that are irretrievably lost (Laqueur, 2002), and the challenge to construct a memorial form that represents both the dead and those who survived.

Ware's article on the history of the Muslim Soldier's Burial Ground in Woking, Surrey, particularly its recent redevelopment and inauguration as a Peace Garden, and the framing of this narrative by the British Government and Military, explores the concept of 'military multiculture'. The representations of the Peace Garden promoted by the state are shown to be highly strategic, responding to contemporary political needs. As a symbol of the contribution of Muslim soldiers fighting as part of the British Empire in World Wars I and II, the site became a focal point for the depiction of a positive history of Muslim-British identity, explicitly promoted to counteract extremist ideologies, both Far-Right and Islamist, and to enhance the image of the British Army to support their recruitment initiatives amongst Black and minority ethnic communities. Ware's article makes the important point that military multiculture is a form of inclusion, in that it broadens membership of a British military heritage to hitherto marginlised groups, but also reiterates an exclusionary militarist discourse on who has 'earned' the right to belong, privileging combat and sacrifice in war over other ways of contributing to society. 
Unlike the bodies of the romusha which are irretrievably lost in unmarked graves, and the bodies of the Muslim soldiers, safely reburied in Brookwood cemetery, Congram's article on Canada's war dead focuses on the instability of 'bodies on the move' (Vedery, 1999), the active search for missing bodies, and the repatriation of those that are found. The mobilising of Empire in global warfare produces war dead buried thousands of miles from their families and communities, and raises questions over whether those bodies should rest abroad, in perpetuity. Congram charts the history of Canada's policy on the recovery and repatriation of war dead from World War I to contemporary conflicts. The shifts in tone, emphasis, and practical implementation that can be noted in the treatment of the dead mirror Canada's move from the influence of the British Empire, latterly the Commonwealth, toward the influence of the United States. Citing the United States' repatriations of soldiers' remains from Iraq, and Canada's recent repatriations of military casualties from Afghanistan, this article touches upon the double-edged nature of repatriation. The return of war dead can bring comfort and closure to relatives and communities, but also brings the society as a whole into an uncomfortable confrontation with the reality of war, as media representations of the dead are circulated and the repatriations become a focus of both commemoration and protest.

My article on the exhumation, identification, and reburial of Australian casualties from the World War I battle of Fromelles, in Northern France, echoes many of the themes identified in Congram's discussion of Canadian War dead. As well as anxieties provoked by the geographical distance between the dead and their living descendants, the theme of temporal distance and the transmission of memory within families and the wider society is also explored. The concept of postmemory, the breakdown of family and community histories, and the active project to reclaim these histories is also explored in both Oliver's and Ware's articles. In the case of the Fromelles families, the struggle to construct personally meaningful ways to commemorate the dead can conflict with official narratives and initiatives to bring the history of Fromelles to a wider public. This article explores the impact when a site becomes part of a war heritage trail, with the accompanying rise in visitor numbers, the development of infrastructure, and highly determined official interpretations (Sumartojo, 2014), all posing a threat to Fromelles' intangible qualities of affect and authenticity. 
Both the Canadian and Australian examples detailed here highlight a central problem of what happens when a policy regarding war dead evolves over time. Casualties from the same army, and even the same war or battle, may end up being treated very differently. In the case of Fromelles, a proportion of the dead have been DNA tested and have individual graves, whereas the majority are unidentified, and remain buried in group graves. Since much of the rationale in the treatment of the dead since World War I, and particularly the rhetoric with which these polices were framed, strives to emphasise equality in death, regardless of rank or nationality, the disparity in treatment arising from new policies and new technologies can be highly destabilising (Wagner and Rosenblatt, 2016).

The issue of equality surfaces multiple times in these papers. Tensions around the treatment of these soldiers' remains in death are strongly bound up with perceived injustices in the treatment of colonial forces during their military service, and the care taken to commemorate their bodies becomes a proxy indicator of the esteem in which their service and sacrifice is now held. This is evident in the depth of anger still felt by some Fromelles families regarding the British command of Australian forces, and the perception that strategic errors in that battle resulted in devastating casualties. The recovery and commemoration of the Fromelles dead is perceived, to some degree, as a counterbalance to these historical injustices. Similarly, Ware notes that the attention paid by the British military to culturally and religiously appropriate post-mortem care for Indian soldiers was explicitly directed at maintaining morale during wartime and countering German propaganda. (Barrett (2007) also exposes the extent to which post-mortem care of Indian soldiers was strategic and selective during World War I and its aftermath.)

Underpinning this preoccupation with equality of treatment is the central tension of the highly unequal power relations under which all these examples of military service, or labour, occurred. For surviving descendants of the dead, it can be very difficult to discern the motivations and agency of individuals sucked in to global conflicts as imperial subjects. For example, the loyalty to the British Empire that motivated many volunteer soldiers in Canada and Australia may be uncomfortable, or incomprehensible, for some of their contemporary descendants, but to deny these imperial sentiments is to de-historicise the dead. Equally, more complex or ambivalent sentiments may be in play, as seen in India and Indonesia, where the experiences of 
World War II are inextricably bound up with the fight for independence from colonial rule. The forces that brought these individuals into war reflect their layered identities as colonial subjects. The families, communities and governments engaged in remembering these histories are left with the question of what it means to have served in, or died for, a colonial or imperial force. And is it possible to represent these multilayered identities and motives in the commemoration of the dead?

\section{Acknowledgements}

Many of these themes surrounding the recovery and commemoration of war dead in post-colonial contexts, were first explored in a symposium held at Kingston University in September 2015. I gratefully acknowledge the support of the Society for Postmedieval Archaeology and Kingston University's Faculty of Science, Engineering and Computing in convening that symposium. I would also like to thank the other speakers and attendees at that event for their valuable insights. Special thanks are due to Professor Rachel Woodward for her excellent editorial guidance and support in preparing all the papers in this issue.

\section{References}

Barrett, M. (2007) Subalterns at War, Interventions, 9:3, 451-474

Capdevilla, L. and Voldman, D. (2006) War Dead: Western Societies and the Casualties of War, Edinburgh: University Edinburgh

Das, S. (2011) 'Introduction' in S. Das (ed) Race, Empire and First World War Writing. Cambridge: Cambridge University Press, 1-32.

Gouda, F. (2014) 'Divided Memories of World War II in the Netherlands and the Dutch East Indies'. In D. Chirot, S. Gi-Wook, eds. 2014. Confronting Memories of World War II: European and Asian Legacies. Washington: University of Washington Press. $105-134$.

Hovinga, H. (2005) 'End of a Forgotten Drama: The Reception and Repatriation of Romusha after the Japanese Capitulation'. In: P. Kratoska, ed. 2005. Asian Labor in the Wartime Japanese Empire: Unknown Histories. New York: M.E. Sharpe, 213 234. 
Laqueur, T.W (2002) The Dead Body and Human Rights. In I. Hodder and S.

Sweeney (eds). The Body. Cambridge: Cambridge University Press.

Sumartojo, S. (2014) Anzac kinship and national identity on the Australian remembrance trail In Sumartojo, S., \& Wellings, B. (Eds.) Nation, Memory and Great War Commemoration: Mobilizing the Past in Europe, Australia and New Zealand.

Oxford: Peter Lang, 45-60.

Verdery, K. (1999) The Political Lives of Dead Bodies: Reburial and Postsocialist Change. New York: Columbia University Press

Wagner, S. and Rosenblatt, A. (2016) Known Unknowns: Forensic Science, the Nation State and the Iconic Dead In Stojanowski, C.M. and Duncan, W.N. Studies in Forensic Biohistory. Cambridge: Cambridge University Press, 237-266

Wellings, B. (2014) Lest You Forget: Memory and Australian Nationalism in a Global Era In Sumartojo, S., \& Wellings, B. (Eds.) Nation, Memory and Great War Commemoration: Mobilizing the Past in Europe, Australia and New Zealand. Oxford: Peter Lang, 45-60. 